Rev. Mus. Argentino Cienc. Nat., n.s.

7(1): 43-49, 2005

Buenos Aires, ISSN 1514-5158

\title{
Equisetites pusillus sp. nov. from the Aptian of Patagonia, Argentina
}

\author{
Liliana VILLAR de SEOANE \\ CONICET - División Paleobotánica, Museo Argentino de Ciencias Naturales «Bernardino Rivadavia», Av. \\ Angel Gallardo 470, (1405) - Buenos Aires. E-mail: Ivillar@macn.gov.ar
}

\begin{abstract}
Compressions of fertile equisetacean branches belonging to the new species Equisetites pusillus are described using light microscopy. The specimens were collected at the Estancia Bajo Tigre locality in strata referred to the Anfiteatro de Ticó Formation, Baqueró Group (Aptian) from the Santa Cruz province, Argentina. The fertile stems bear an oval and solitary terminal cone with spores. The spores are alete, circular and without elaters. Equisetites pusillus $s p$. nov . is compared with other fossil equisetacean taxa from Argentina and elsewhere. The spores are compared with those of two extant Equisetum species from Argentina, and also with other mesozoic taxa. The compressions were found in sediments rich in organic matter, deposited in shallow waters surrounded by environments colonized by sphenophytes, ferns and bryophytes. This type of landscape was frequent during the Aptian originating a common type of deposit (lenticular) in the Anfiteatro de Ticó Formation.
\end{abstract}

Key words: Equisetaceae, cones, spores, Aptian, Patagonia, Argentina.

The genus Equisetites was established by Sternberg (1833) for specimens of the European Triassic, preserved as casts, impressions and com-pressions having similar morphological charac-ters with the extant genus Equisetum L.

Since the early years of the last century, Equisetites was frequently reported in Mesozoic sediments of Argentina and Antarctica. Halle (1913) described the first equisetacean stems from the Middle Jurassic of Antarctica. Roots and stems of a new species (Equisetites fertilis) from the Triassic of San Juan and Mendoza provinces were described by Frenguelli (1944 a). Stems with leaf-sheaths (Equisetites frenguellii) were ana-lyzed by Orlando (1946) for the Lower Jurassic of Neuquén province. Archangelsky (1964) de-scribed new stems (Equisetites sp.) from the Lower Cretaceous of Santa Cruz province; and Herbst (1964, 1965, 1966 a, b and c) found dif-ferent stems (Mendoza and Neuquén provinces), and created a new taxon (Equisetites patagonica) from the Liassic of Roca Blanca Formation, in Patagonia.

Menéndez (1958) described the first fertile specimens as Equisetites quindecimdentata from the Upper Triassic of San Juan province. The cones although incomplete show sporangiophores and sporangia.

In the present paper, three fertile specimens of the new species Equisetites pusillus from the Aptian of Santa Cruz province are described using light microscopy. This is the first Equisetites species with spores found in the Mesozoic of Argentina.

\section{MATERIALS AND METHODS}

The fertile specimens occur at Estancia Bajo Tigre, Anfiteatro de Ticó Formation, Baqueró Group (Cladera et al., 2002). The site was first mentioned by Archangelsky (1967) and is located at $48^{\circ} 30^{\prime} 33^{\prime \prime}$ $\mathrm{S}$ and $69^{\circ} 14^{\prime} 11^{\prime \prime} \mathrm{W}$, in the Deseado Massif of the Santa Cruz province (Argentina), and is of Aptian age (120 Ma; Corbella, 2001).

The specimens are well preserved compressions and were collected in organically rich sediments that were deposited to river banks or seasonal lagoons, and associated with ferns and bryo-phytes belonging to plant communities that lived near shallow waters.

The material was studied with a Leica MZ 12.5 stereoscopic microscope and photographed with a Canon camera. One specimen was partially treated with $\mathrm{HF}$ and $\mathrm{HCl}$, and the residue was mounted in glycerine jelly for its observation with light microscopy. The spores were studied using a Leitz Diaplan microscope, measured using the Leica QWin software and photographed with a Leica DFC 280 camera.

The material is deposited in the Paleobotanical Collection of the Argentine Museum of Natural Sciences «Bernardino Rivadavia» with the acronyms BA Pb (specimens) and BA Pb Pm (microscopic slides). 


\section{SYSTEMATIC DESCRIPTIONS}

\author{
Division Sphenophyta \\ Order Equisetales
}

Family Equisetaceae Michx. ex DC., 1804

Genus Equisetites Sternberg, 1833

Type Species. Equisetites muensteri Sternberg, 1833

\section{Equisetites pusillus sp. nov.}

(Fig. $1 \mathrm{~A}-\mathrm{I}$ )

1964. Equisetites sp., Archangelsky, pgs. 225226, figs. 1-3.

Holotype. BA Pb 13501.

Paratypes. BA Pb 13502; and BA Pb 13503, BA $\mathrm{Pb} \mathrm{Pm}$ 465, BA Pb Pm 466.

Type locality . Estancia Bajo Tigre, Santa Cruz province, Argentina

Stratigraphic horizon. Fossiliferous bed BTO, Anfiteatro de Ticó Formation, Baqueró Group, Aptian.

Derivation of name. Refers to the small size of the cones.

Diagnosis. Stems $3 \mathrm{~mm}$ wide of unknown length, with 2 to 3 ridges, internodes $5-10 \mathrm{~mm}$ long and leaf-sheaths with 12 - 13 leaves at nodal diaphragms. Apical, single cones with rounded apex and convex sides supported by bracts. Spo-rangiophores helically arranged. Rhomboidal to hexagonal sporangiophore heads up to $1 \mathrm{~mm}$ in diameter. Alete spores, circular to subcircular outline, 46 - $69 \mu \mathrm{m}$ in diameter. Exine smooth to slightly scabrate, thinner in the central region, without elaters.

Description. Equisetites pusillus sp. nov. is represented by sterile and fertile compressions with sporangiophores lacking cuticle. The fertile stem fragments are probably terminal branches, but the main axis was not found.

Specimen BA Pb 13501 has a stem 2 mm wide and $20 \mathrm{~mm}$ long with three well defined ridges. At the base of the apical cone, the stem is en-larged bearing six imbricate and lanceolate bracts having rounded apexes (Fig. 1B). The stem is topped by an oval cone $5 \mathrm{~mm}$ wide and 6 $\mathrm{mm}$ long, with a rounded apex and convex sides (Fig. 1B). The helically arranged sporangiophores have a rhomboidal external head. Each shield has a de-pressed upper margin and a rising lower margin (Fig. 1B). Sporangia are not visible.

Specimen BA Pb 13502 is a small stem fragment bearing a terminal cone. The branch is thin, up to $2.7 \mathrm{~mm}$ wide and $3.5 \mathrm{~mm}$ long. It has two longitudinal ridges, however nodes, internodes or leaf-sheaths are not seen. The branch ends with an irregular transversal margin (Fig. 1C). The cone is complete and oval, $5 \mathrm{~mm}$ wide and 6.5 $\mathrm{mm}$ long, with a rounded apex and convex sides. The sporangiophores are arranged helically. They are rhomboidal, $1 \mathrm{~mm}$ in diameter, with a slightly depressed central area (Fig. 1C). Sporangia are not seen.

Specimen $\mathrm{BA} \mathrm{Pb} 13503$ is a fragment of stem bearing a terminal cone. The stem is thin, $2 \mathrm{~mm}$ wide and $32 \mathrm{~mm}$ long. It has two evident ridges, but leaf-sheaths are not observed (Fig. 1A). The cone is incomplete and wedge-shaped, $5 \mathrm{~mm}$ wide and 5 $\mathrm{mm}$ long, with truncate apex and convex sides. The sporangiophore heads are slightly marked and have a rhomboidal to hexagonal out-line (Fig. 1A). This cone fragment was chemically treated and in the residue inaperturate spores and few Classopollis pollen grains (conifer fam-ily Cheirolepidiaceae) were found.

The spores are alete with a thinner exine (leptome) in the central region. They have a circular to subcircular outline and a diameter of 46.5 - $68.2 \mu \mathrm{m}$. The exine is $1.30-2.20 \mu \mathrm{m}$ thick, smooth or slightly scabrate. Frequent folds oc-cur on the spore surface. Elaters are not present (Fig. 1D - I). Abundant remnants of the tapetal membrane are adhered to the spores. Isolated Ubisch bodies are also irregularly distributed on the tapetal membrane and the spore surface, being more conspicuous on the former (Fig. 1E - H).

Equisetites sp. (Archangelsky, 1964) from the Anfiteatro de Ticó Formation (Lower Cretaceous of Santa Cruz province) has sterile branches up to $3 \mathrm{~mm}$ wide, with internodes $5-10 \mathrm{~mm}$ long and leaf-sheaths with 12 - 13 leaves at the nodal diaphragms. This material was found at the Anfiteatro de Ticó locality in a kaolinic bed in which poorly preserved bennettitalean and filicinean remains also occur (Archangelsky, op. cit.) . Equisetites $s p$. is interpreted as the vegetative stems of Equisetites pusillus, and is included in the new species.

The palynological records of the Baqueró Group show the presence of equisetalean- type spores, being described as Calamospora aff. mesozoica Couper 1958. During Mesozoic times, there were equisetalean plants that have produced two types of spores, some with trilete laesura and others inaperturate (Archangelsky \& Villar de Seoane, 1994).

Comparisons with similar species. Several equisetacean species are known in the Mesozoic and Cenozoic of Argentina. Table 1 shows their sizes and morphological characters, the tiny 

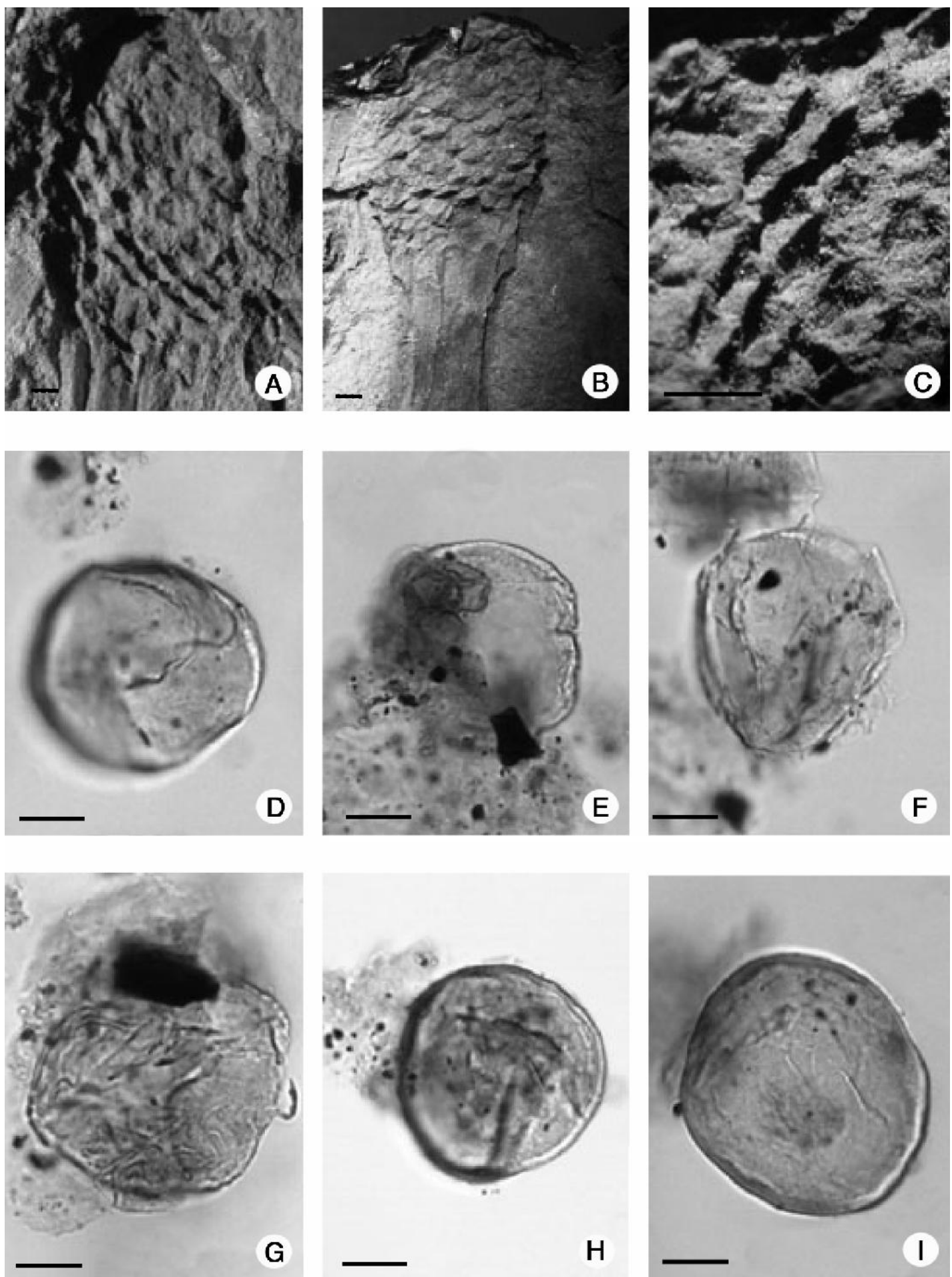

Fig. 1. A-I. Equisetites pusillus sp. nov. B-C, BA Pb 13501, holotype, B, General view of the fertile branch. C, Detail of the cone, BA Pb 13502, paratype, A, General view of the cone. BA Pb 13503, paratype, D-I, BA Pb Pm 466, D and I, General view of a spore with folds on its surface. E-H, Details of the spores with tapetal membrane and Ubisch bodies. Scale bars represent: $A-C=1 \mathrm{~mm}, \mathrm{D}-\mathrm{I}=20 \mu \mathrm{m}$. 
stems of Equisetites pusillus sp. nov. being only comparable to Equisetites quindecimdentata

Menéndez, a fertile species with axes bearing ter-minal cones, found in the Upper Triassic of Hilario, San Juan province. The fertile stems are up to $37 \mathrm{~mm}$ wide, and have internodes, leafsheaths and stellate nodal diaphragms. The axes end in terminal, incomplete and large cones (up to $20 \mathrm{~mm}$ wide) with strongly umbonate sporangiophores and triangular to subtriangular sporangia (Menéndez, 1958). This species differs from

Equisetites pusillus $s p$. nov. in having larger cones and sporangiophores.

Equisetites fertilis (Frenguelli) Frenguelli from the Upper Triassic of the Quebrada de Los Rastros (San Juan province) and Potrerillos For-mation (Mendoza province) includes specimens firstly referred to Macrotaenia fertilis Frenguelli (1943 a) and Equisetites scitulus Frenguelli (1943 b). A new interpretation of the fragments that were originally thought to be leaves bearing fer-tile bodies, allowed Frenguelli (1944 b) to pro-pose the new combination Equisetites fertilis. This is the most complete sterile species found thus far in Argentina. It has thin roots, stems up to $45 \mathrm{~mm}$ wide, leaf-sheaths and stellate nodal dia-phragms (Frenguelli, 1944 b). Equisetites fertilis does not have cones and the stems are larger than

Equisetites pusillus sp. nov.

Palynological comparisons. Few fertile species with preserved spores are known in the Mesozoic of Laurasia and Gondwana.

The spores of Equisetites pusillus sp. nov. are mostly comparable with Pilasporites allenii, and spores found in cones of Equisetites muensteri, Equisetites lyellii and Equisetostachys suecicus. They share the size and the exine ornamentation (see Table 2).

Watson (1983), and Watson \& Batten (1990) found globose and alete spores (28 - $48 \mu \mathrm{m}$ in diameter) with a smooth or scabrate exine and without elaters in the cones of Equisetum Iyellii Mantell, from the Wealden of Sussex (England). These spores are similar to Pilasporites allenii Batten.

Batten (1968) described Pilasporites allenii from the soil-bed sediments from the Wadhurst Clay in the southern region of England (Lower Cretaceous), finding circular and alete spores with a smooth or scabrate exine and a mean diameter of $36.7 \mu \mathrm{m}$. These spores lack elaters.

Equisetites muensteri Sternberg from the Upper Triassic of Greenland (Harris, 1931) has rounded spores $40-50 \mu \mathrm{m}$ in diameter, with thin and smooth wall without elaters. He discussed the absence of elaters suggesting that they may have been destroyed during the fossilization or preparation of the spores. Halle (1908) and Batten (1968) shared this opinion.

Halle (1908) described two species of Equisetostachys from the Rhaeto-Liassic of Sweden: E. nathorstii and E. suecicus. The first species has globose and usually folded spores with a short trilete mark and smooth exine. They are 35 - $40 \mu \mathrm{m}$ in diameter. E. suecicus spores are slightly larger (40 - $50 \mu \mathrm{m})$, alete and smooth.

The spores of Equisetites pusillus sp. nov. also differ from other species, in the size and the ex-ine ornamentation (see Table 2).

Harris (1978) found spores with attached elaters in the cones of Equisetum columnare Brongniart from the Middle Jurassic of Yorkshire (England). These spores are globose, alete, about $40-50 \mu \mathrm{m}$ in diameter and have a scabrate exine.

Equisetum laterale Phillips from the Lower Jurassic of Australia has ovate and terminal cones with numerous spores. They are small (24 - $41 \mu \mathrm{m}$ in diameter), globose and alete with a scabrate to microrugulate exine (Gould, 1968).

Vozenin -Serra \& Laroche (1976) studied spores from Equisetum boureaui Vozenin-Serra \& Laroche from the Chres Formation (Upper Triassic of Western Cambodia). These spores are $30 \mu \mathrm{m}$ in diameter and have an ornamented exine.

Equisetites arenaceus (Jaeger) Schenk from the Upper Triassic (Keuper) of Germany has three cones attached to the fertile branches. The cone has sporangiophore heads bearing a circle of sporangia on their lower surface. They include globose spores (50 - $60 \mu \mathrm{m}$ in diameter), alete or with a small trilete, and scabrate to microrugulate exine. None of these spores showed any attached elaters, except in one case in which there was a possible indication of this structure (Kelber \& van Konijnenburg-van Cittert, 1998).

Discussion. The Equisetales include two families: Calamitaceae and Equisetaceae. Both have similar morphological and anatomical characters, such as the structure of the primary vascular tissue and the presence of spores with elaters (Taylor \& Taylor, 1993).

The Calamitaceae are Paleozoic and differ from the Equisetaceae (mostly Mesozoic to recent) in having arborescent habits. They present secondary vascular tissue, larger leaves and cones with a different morphology, size and position. The cones may be mono, bisporangiate or grouped in nodal sporangiophores, being axial in the branches or in terminal bracts (Taylor \& Taylor, op. cit.).

The geological history of the equisetalean plants begins in the Devonian and has its most 
Table 1. Comparison between the different fossil Equisetites and Equisetum of Argentina.

\begin{tabular}{|c|c|c|c|c|c|c|c|c|c|}
\hline Species & $\begin{array}{l}\text { Equisetites } \\
\text { pusillus } \\
\text { sp.nov. }\end{array}$ & $\begin{array}{c}\text { Equisetites } \\
\text { approximatus } \\
\text { Nathorst } \\
\text { (Halle, 1913) }\end{array}$ & $\begin{array}{l}\text { Equisetites } \\
\text { fertilis } \\
\text { Frenguelli } \\
1944\end{array}$ & $\begin{array}{c}\text { Equisetites } \\
\text { frenguellii } \\
\text { Orlando } \\
1946\end{array}$ & $\begin{array}{c}\text { Equisetites } \\
\text { patagonica } \\
\text { Herbst } \\
1965\end{array}$ & $\begin{array}{c}\text { Equisetites } \\
\text { quindecimdent. } \\
\text { Menéndez } \\
1958\end{array}$ & $\begin{array}{c}\text { Equisetites sp. } \\
\text { (Frenguelli, } \\
\text { 1944) }\end{array}$ & $\begin{array}{c}\text { Equisetites sp. } \\
\text { (Archangelsky, } \\
1964)\end{array}$ & $\begin{array}{c}\text { Equisetum sp. } \\
\text { (Durango } \\
\text { de Cabrera et al., } \\
\text { 1997) }\end{array}$ \\
\hline Age & Lower Cretaceous & Mid. Jurassic & Upper Triassic & Lower Jurassic & Lower Jurassic & Upper Triassic & Upper Triassic & Lower Cretaceous & Upper Miocene \\
\hline $\begin{array}{l}\text { Geographic } \\
\text { locality }\end{array}$ & $\begin{array}{c}\text { Santa Cruz } \\
\text { province }\end{array}$ & Antarctica & $\begin{array}{l}\text { San Juan - } \\
\text { Mendoza } \\
\text { provinces }\end{array}$ & $\begin{array}{l}\text { Neuquén } \\
\text { province }\end{array}$ & $\begin{array}{c}\text { Mendoza - } \\
\text { Neuquén - } \\
\text { Chubut - } \\
\text { Santa Cruz prov. }\end{array}$ & $\begin{array}{l}\text { San Juan } \\
\text { province }\end{array}$ & $\begin{array}{l}\text { Mendoza } \\
\text { province }\end{array}$ & $\begin{array}{l}\text { Santa Cruz } \\
\text { province }\end{array}$ & $\begin{array}{l}\text { Catamarca } \\
\text { province }\end{array}$ \\
\hline Stem (wide) & $2.7 \mathrm{~mm}$ & $25-30 \mathrm{~mm}$ & $45 \mathrm{~mm}$ & $8 \mathrm{~mm}$ & $11-24 \mathrm{~mm}$ & $2.5 \mathrm{~mm}$ & $14 \mathrm{~mm}$ & $3 \mathrm{~mm}$ & $5-20 \mathrm{~mm}$ \\
\hline Internodes & & $25 \mathrm{~mm}$ & $38-45 \mathrm{~mm}$ & & $30-35 \mathrm{~mm}$ & 8-30 mm & & $5-10 \mathrm{~mm}$ & \\
\hline $\begin{array}{l}\text { Nodal } \\
\text { diaphragm }\end{array}$ & & & & & $3.5-7 \mathrm{~mm}$ & & & & \\
\hline Leaves & & $15-35$ & & 12 & $28-38$ & 15 & 14 & $12-13$ & \\
\hline Leaf-sheath & & & 8-13 mm & $10 \mathrm{~mm}$ & $10-12 \mathrm{~mm}$ & $21 \mathrm{~mm}$ & $15 \mathrm{~mm}$ & $1-3 \mathrm{~mm}$ & \\
\hline Cones & $5-6.5 \mathrm{~mm}$ & & & & & $20 \mathrm{~mm} ?$ & & & \\
\hline $\begin{array}{l}\text { Sporangio- } \\
\text { phores }\end{array}$ & $1 \mathrm{~mm}$ & & & & & $2-2.5 \mathrm{~mm}$ & & & \\
\hline Spores & $47-68 \mu \mathrm{m}$ & & & & & & & & \\
\hline Species & $\begin{array}{c}\text { Equisetites } \\
\text { pusillus sp. nov. }\end{array}$ & $\begin{array}{c}\text { Equisetites } \\
\text { arenaceus } \\
\text { (Jaeger) } \\
\text { Schenk } \\
\text { (Kelber \& Van } \\
\text { Cittert, 1998) }\end{array}$ & $\begin{array}{c}\text { Equisetites } \\
\text { lyellii Mantell } \\
\text { (Watson, 1983) }\end{array}$ & $\begin{array}{c}\text { Equisetites } \\
\text { muensteri } \\
\text { Sternberg } \\
1833\end{array}$ & $\begin{array}{c}\text { Equisetum } \\
\text { boureaui } \\
\text { Vozenin-Serra } \\
\text { \& Laroche } \\
1976\end{array}$ & $\begin{array}{c}\text { Equisetum } \\
\text { columnare } \\
\text { Brongniart } \\
\text { (Harris, 1978) }\end{array}$ & $\begin{array}{c}\text { Equisetum } \\
\text { laterale } \\
\text { Phillips } \\
\text { (Gould, 1968) }\end{array}$ & $\begin{array}{l}\text { Equisetosta- } \\
\text { chys nathorstii } \\
\text { Halle } 1908\end{array}$ & $\begin{array}{l}\text { Equisetosta- } \\
\text { chys suecicus } \\
\text { Halle } 1908\end{array}$ \\
\hline Age & Lower Cretaceous $L$ & Jpper Triassic & Lower Cretaceous & Upper Triassic & Upper Triassic & Middle Jurassic & Middle Jurassic & Lower Jurassic & Lower Jurassic \\
\hline $\begin{array}{l}\text { Geographic } \\
\text { locality }\end{array}$ & Argentina & Germany & England & Australia & $\begin{array}{l}\text { Cambodge } \\
\text { Occidental }\end{array}$ & England & Australia & Sweden & Sweden \\
\hline $\begin{array}{l}\text { Spores: } \\
\text { diameter }\end{array}$ & $47-68 \mu \mathrm{m}$ & $50-60 \mu \mathrm{m}$ & $28-48 \mu \mathrm{m}$ & $40-50 \mu \mathrm{m}$ & $30 \mu \mathrm{m}$ & $40-50 \mu \mathrm{m}$ & $24-41 \mu \mathrm{m}$ & $35-40 \mu \mathrm{m}$ & $40-50 \mu \mathrm{m}$ \\
\hline aperture & alete & $\begin{array}{l}\text { alete or } \\
\text { trilete }\end{array}$ & alete & alete & - & alete & alete & trilete & alete \\
\hline exine & smooth & $\begin{array}{l}\text { scabrate to } \\
\text { microrugulate }\end{array}$ & $\begin{array}{l}\text { smooth or } \\
\text { scabrate }\end{array}$ & smooth & smooth & scabrate & $\begin{array}{l}\text { scabrate to } \\
\text { microrugulate }\end{array}$ & smooth & smooth \\
\hline elaters & - & only one case & - & - & - & yes & - & - & - \\
\hline
\end{tabular}




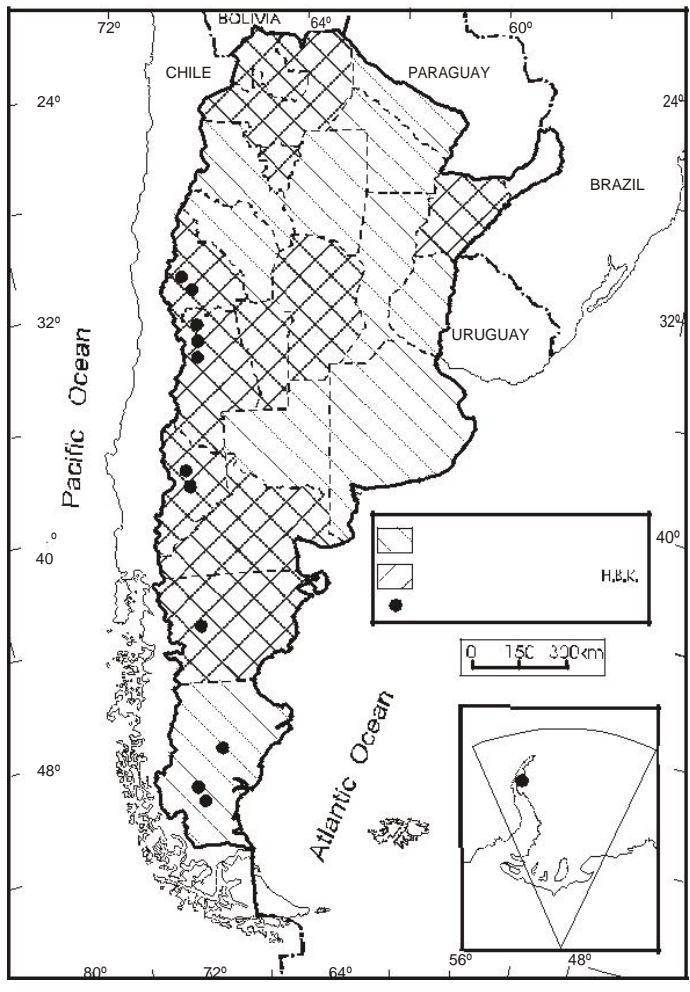

Fig. 2. Map of Argentina showing the distribution of the fossil genus Equisetites Sternberg and the living species Equisetum bogotense H.B.K. and Equisetum giganteum L.

important development during the Carboniferous, where it is possible that both families coexisted or the Equisetaceae evolved from the Calamitaceae. The first known equisetacean remains are Triassic, and in Argentina the oldest Equisetites species are of Early Triassic age.

Up to now, specimens of Equisetites have been found in Mesozoic strata of San Juan, Mendoza, Neuquén, Chubut and Santa Cruz provinces (Argentina), and in the Jurassic of Antarctica (Fig. 2).

At present, the Equisetaceae are represented by one genus: Equisetum L., with approximately 30 herbaceous species, with terminal cones and sporangiophores arranged in whorls, and a worldwide distribution, except Australia. The spores are spheroidal, with a very small aperture, granulate surface with scattered spherules and two long and spathulate elaters coiled around the body (Tryon \& Lugardon, 1991).

In Argentina, two extant species are known to occur growing crowded in moist or wet places: Equisetum giganteum L. and Equisetum bogotense H.B.K., both with an extended geographical distribution.
E. giganteum $\mathrm{L}$. is a large plant with elongated cones $4 \mathrm{~mm}$ wide and $8 \mathrm{~mm}$ long. The spores are $54 \mu \mathrm{m}$ in diameter and have two elaters. The species is found in all Argentinean provinces, except Misiones and Tierra del Fuego (Ponce, 1996) (Fig. 2).

E. bogotense H.B.K. is a small plant (15 - 20 $\mathrm{cm}$ high) with oblong cones $3 \mathrm{~mm}$ wide and 6-8 $\mathrm{mm}$ long. The spores are $40 \mu \mathrm{m}$ in diameter and have two elaters. This species occurs in Jujuy, Salta, Tucumán, Corrientes, Córdoba, San Juan, San Luis, Mendoza, Neuquén, Río Negro and Chubut provinces (Ponce, op. cit.) (Fig. 2) and has a similar size to Equisetites pusillus sp. nov.

\section{CONCLUSIONS}

In the Baqueró Group, equisetalean remains are very scarce, and Equisetites pusillus sp. nov. becomes an important addition because of its fertile condition including spores, that are first mentioned for the Anfiteatro de Ticó Formation, and indeed for the Cretaceous of Argentina.

The stems and cones of Equisetites pusillus are similar to the other Argentinean and Gondwanan fossil species except for their sizes, while the northern Equisetites arenaceus differs in having three cones per branch.

The spores of Equisetites pusillus are similar to the fossil Pilasporites allenii and those of Equisetites muensteri, Equisetites lyellii and Equisetostachys suecicus. They are alete, have a smooth surface and their diameters are similar.

The fertile branches and the cones of Equisetites pusillus are similar to those of the extant Equisetum bogotense, except that the fossil spores lack elaters.

\section{ACKNOWLEDGEMENTS}

Thanks are due to Dr. Sergio Archangelsky for valuable suggestions that improved the original manuscript, and for providing the fossil material; Angel Fusaro for photographic assistance; Luis Lezama for technical support in the figure 1; and Amalia González for the map drawing. This research has been supported by the Grant ANPCYT PICT 99 07-06044.

\section{BIBLIOGRAPHY}

Archangelsky, S. 1964. Notas sobre la Flora Fósil de la Zona de Ticó, provincia de Santa Cruz. Ameghiniana 3: 221-226.

1967. Estudio de la Formación Baqueró, Cretácico Inferior de Santa Cruz, Argentina. Rev. Mus. La Plata (N.S.) Pal. 5: 63-171. 
Archangelsky, S. \& L. Villar de Seoane. 1994. Estudios palinológicos de la Formación Baqueró (Cretácico), Provincia de Santa Cruz, Argentina. VI. Ameghiniana 31: 41-53.

Batten, D.J. 1968. Probable dispersed spores of Cretaceous Equisetites. Palaeontology,11: 633-642.

Cladera, G., R. Andreis, S. Archangelsky \& R. Cúneo. 2002. Estratigrafía del Grupo Baqueró, Patagonia (provincia de Santa Cruz, Argentina). Ameghiniana 39: 3-20.

Corbella, H. 2001. Tuffs of the Baqueró Group and the Mid-Cretaceous frame, Extraandean Patagonia, Argentina. XI Congreso Latinoamericano de Geología y III Congreso Uruguayo de Geología. Trabajo 190 (En CD).

Couper, R.A. 1958. British mesozoic microspores and pollen grains. Palaeontographica B, 103: 75-179.

Durango de Cabrera, J., S. Georgieff \& P. Moreno. 1997. Primer registro del género Equisetum Linneo (Pteridophyta) en la Formación Andalhuala (Mioceno Superior), Valle de Santa María, Catamarca. Ameghiniana 34: 119.

Frenguelli, J. 1943 a. Contribuciones al conocimiento de La Flora del Gondwana Superior en la Argentina XI. Macrotaenia fertilis gen. et sp. nov. Notas Mus. La Plata 8, Pal. 57: 401-411.

- 1943 b. Contribuciones al conocimiento de La Flora del Gondwana Superior en la Argentina XIII.

Equisetites scitulus sp. nov. Notas Mus. La Plata 8, Pal. 59: 417-420.

- 1944 a. Contribuciones al conocimiento de la Flora del Gondwana Superior en la Argentina. XV. La Flórula de la Base de la «Serie de Cacheuta» en el Cerro de los Baños, Mendoza. Notas Mus. La Plata 9, Pal. 63: 271-310.

- 1944 b. Contribuciones al conocimiento de la Flora del Gondwana Superior en la Argentina. XXIV. Equisetites fertilis n. comb. Notas Mus. La Plata 9 , Pal. 73: 501-509.

Gould, R.E. 1968. Morphology of Equisetum laterale Phillips 1829, and E. bryanii sp. nov. from the Mesozoic of South-eastern Queensland. Australian J. Bot. 16: 153-176.

Halle, T.G. 1908. Zur Kenntnis der mesozoischen Equisetales Schwedens. Kungl. Svenska Vetenskapsakademiens Handlingar 43: 3-40.

1913. The Mesozoic Flora of Graham Land. Wi- Wa ssenschaftliche Ergebnisse der Schwedischen Südpolar-expedition 1901-1903 unter Leitung von Dr. Otto Nordenskjöld 3 (14): 1-123.

Harris, T.M. 1931. The Fossil Flora of Scoresby Sound East Greenland. Part 1: Cryptogams (exclusive of
Lycopodiales). Meddelelser Om GrØnland 85 (2): 1-102.

- 1978. A reconstruction of Equisetum columnare and notes on its elator bearing spores. Palaeobotanist 25: $120-125$.

Herbst, R. 1964. La flora liásica de la zona del Río Atuel, Mendoza, Argentina. Rev. Asoc. Geol. Arg. 19 (2): 108-131.

- 1965. La Flora Fósil de la Formación Roca Blanca, provincia de Santa Cruz, Patagonia. Con consideraciones Geológicas y Estratigráficas. Opera Lilloana 12: 1-101.

- 1966 a. Revisión de la Flora Liásica de Piedra Pintada, provincia de Neuquén, Argentina. Rev. Mus. La Plata (N.S.) Pal. 5: 27-53.

- 1966 b. Nuevos elementos florísticos de la Formación Piedra del Aguila, Neuquén, Argentina. Acta Geol. Lilloana 8: 249-254.

- 1966 c. La Flora Liásica del Grupo Pampa de Agnia, Chubut, Patagonia. Ameghiniana 4: 337-349.

Kelber, K.P. \& J.H.A. van Konijnenburg-van Cittert. 1998. Equisetites arenaceus from the Upper Triassic of Germany with evidence for reproductive strategies. Rev. Palaeobot. Palynol. 100, 1-26.

Menéndez, C.A. 1958. Equisetites quindecimdentata sp. nov. Del Triásico Superior de Hilario, San Juan. Rev. Asoc. Geol. Arg. 13 (1): 5-14.

Orlando, H.A. 1946. Equisetites Frenguellii n. sp. del Lias de Piedra Pintada, Neuquén. Notas Mus. La Plata 11, Pal. 91: 269-282.

Ponce, M.M. 1996. Pteridophyta. In: Catálogo de las Plantas Vasculares de la República Argentina. 1. (Eds. F.O. Zuloaga \& O. Morrone). Missouri Botanical Garden, Vol. 60, 323 pp.

Sternberg, C. 1833, 1838. Versuch einer geognostischbotanisch Darstellung der Flora der Vorwelt. Fasc. II. Leipzig.

Taylor, T.N. \& E.L. Taylor. 1993. The Biology and Evolution of Fossil Plants. 982 pp. Prentice Hall, New Jersey.

Tryon, A.F. \& B. Lugardon. 1991. Spores of the Pteridophyta. Springer-Verlag, New York. 648 pp.

Vozenin-Serra, C. \& J. Laroche. 1976. Presence d'une Equisetacée dans les Formations de Chres Cambodge Occidental -. Palaeontographica B 159: 158-166.

n, J. 1983. Two wealden species of Equisetum found in situ. Acta Palaeontol. Polonica 28 (1-2): 265-269.

Watson, J. \& D.J. Batten. 1990. A revision of the English Wealden Flora, II. Equisetales. Bull. Brit. Mus. (Nat. Hist.) Geol. 46: 37-60. 